\title{
Manajemen Pemberitaan Kriminal pada Program Tangkis di iNews TV dalam Memenuhi Kepuasan Pemirsa
}

\section{Crime News Management on Tangkis Program iNews TV in Meets Audience Satisfaction}

\author{
Nurleli \\ Program Studi Ilmu Komunikasi, Fakultas Ilmu Sosial dan Ilmu Politik \\ Universitas Muhammadiyah Sumatera Utara, Indonesia \\ Coressponding: nurleliumsu@gmail.com
}

\begin{abstract}
Abstrak
Manajemen pemberitaan kriminal di televisi sangat menentukan kualitas dari pemberitaan.Mengacu kepada prinsip manajemen yang terdiri dari Planning, Organizing, Actuating dan controling dalam pemberitaan kriminal, sumber daya manusia yang ada melaksanakan tugas secara sistematis pada setiap tahapan manajemen pemberitaan kriminal.Melalui manajemen yang baik, berita kriminal yang dihasilkan relatif dapat memenuhi kepuasan pemirsa berdasarkan motif-motif yang mendorong mereka menggunakan media dan mengkonsumsi berita kriminal yang ditayangkan di iNews TV.
\end{abstract}

Kata Kunci: Manajemen Pemberitaan, Berita Kriminal, Kepuasan Pemirsa

\begin{abstract}
The management of criminal reporting on television is very determining the quality of the news. Referring to the management principles consisting of Planning, Organizing, Actuating and controlling in criminal prosecution, existing human resources perform the task systematically at every stage of criminal reporting management. Through good management, the resulting criminal news relative can satisfy the viewer's satisfaction based on the motives that encourage them to use the media and consume the criminal news that aired on iNews TV.
\end{abstract}

Keywords: News Management, Crime News, Audience Satisfaction

How to Cite: Nurleli, (2017), Manajemen Pemberitaan Kriminal pada Program Tangkis di iNews TV dalam memenuhi Kepuasan Pemirsa, SIMBOLIKA, 3 (2): 78-86. 


\section{PENDAHULUAN}

Semakin banyaknya stasiun televisi swasta saat ini telah menimbulkan persainganantar sesama stasiun televisi untuk merebut pemirsa dalam setiap program siarannya, termasuk program berita.Dengan adanya program berita ini, stasiun televisi memiliki redaksi berita dan tim liputan, yang biasanya berada pada bagian pemberitaan atau news departemen. Sebagian besar stasiun televisi membentuk bagian pemberitaan sebagai suatu unit atau departemen yang terpisah dari bagian program.Bagian pemberitaan biasanya diketuai seorang manajer atau direktur pemberitaan yang bertanggungjawab langsung kepada pimpinan stasiun televisi.

Keberhasilan bagian pemberitaan stasiun televisi banyak bergantung kepada reporter dan juru kamera yang ada di lapangan serta kordinator liputan di ruang redaksi yangmengarahkan mereka, namun demikian kemampuan produser dan eksekutif produser dalam menyusun program acara juga tak kalah pentingnya. Seorang produser harus mensetting berita-berita apa saja yang akan ditayangkan untuk satu kali produksi, kemudian disusun berdasarkan isu-isu yang dianggap penting dalam sebuah rundown berita, dengan tujuan agenda pemberitaan pada media tidak hanya semata-mata untuk pemberitaannya menjadi saluran isu dan peristiwa, tetapi juga merupakan strategi yang dimainkan media sehingga pemberitaan mempunyai nilai lebih terhadap persoalan yang ada. Dalam kaitan ini, McCombs and Shaw mengatakan bahwa "jika media memberikan tekanan pada suatu peristiwa, maka media itu akan mempengaruhi khalayak untuk menganggapnya penting. (Effendy, 2000: 287).

Tentunya untuk menghasilkan sebuah tayangan program berita dibutuhkan sebuah manajemen dalam pemberitaan itu sendiri, dimana proses manajemen itu sendiri merupakan suatu rangkaian proses yang meliputi kegiatan pengorganisasian, pelaksanaan, pengawasan, evaluasi dan pengendalian dalam rangka memberdayakan seluruh sumber daya organisasi/perusahaan, baik sumberdaya manusia, modal material, maupun teknologi secara optimal untuk mencapai tujuan organisasi/perusahaan. Seperti halnya tujuan atau target dari sebuah program berita yang ditayangkan stasiun televisi adalah selain menjaga peringkat acara atau rating agar tetap baik, juga harus memperbaiki mutu program tayangan berita itu sendiri, yang pada akhirnya program berita yang ditayangkan mendapat perhatian dan kepuasan penonton.

iNews TV merupakan televisi nasional berjaringan, yang memiliki jaringan televisi lokal terbanyak dan terluas di Indonesia, salah satunya Deli TV Medan, yang kini menjadi iNews TV Medan. Sebagai televisi lokal berjaringan nasional, iNews TV Medan juga memiliki siaran lokal, yakni program berita kriminal yang dikemas dalam program berita TANGKIS (Tayangan Kriminal Sumatera Utara) yang khusus menayangkan berita kriminal, peristiwa dan hukum.

Sebuah program berita televisi tentunya dikemas semenarik mungkin, dengan tujuan mendapat perhatian dari pemirsa. Mulai dari isu-isu yang ada di masyarakat, sampai pengemasan berita itu sendiri.Sementara informasi seputar kriminal juga menjadi suatu hal yang menarik untuk dijadikan program berita, mengingat angka kriminalitas yang terjadi di Sumatera Utara, khususnya kota Medan terus meningkat, dari 129 kasus pada tahun lalu, menjadi 183 kasus di tahun 2016 ini, mulai dari kasus pembakaran, penganiayaan, pencurian dengan kekerasan, KDRT, pembunuhan, pemerasan, pengunaan dan pemilikan narkoba dan lain lain (koran sindo.com, edisi 12-07-2016).

Tidak saja mengangkat isu kriminal, program berita Tangkis memiliki keunikan sendiri dibandingkan program berita lainnya, mulai dari pengemasan berita, judul berita yang ditampilkan, sampai kepada presenter yang membawa berita Tangkis, memberikan 
kesan dan ingatan yang tajam kepada pemirsanya, salah satunya saat presenter membuka program berita, dengan kalimat yang tegas, dan wajah yang jauh dari kesan senyum, "Hallo pemirsa, apakabar...kita bertemu lagi dalam program TANGKIS," dimana presenter mengepalkan kedua tangan dan membentuk letter T," simbol dan karaktertegas inilah menjadi ciri khas dari program Tangkis dan sangat melekat dalam ingatan masyarakat, sehingga pemirsa lebih mengingat program berita Tangkis di iNews TV.

\section{METODE PENELITIAN}

Jenis penelitian ini adalah penelitian dengan pendekatan deskriptif kualitatif. Teknik pengumpulan data menggunakan wawancara mendalam. Dalam penelitian ini akan dikemukakan manajemen pemberitaan kriminal pada program Tangkis di iNews TV dalam memenuhi kepuasan pemirsa.

Informan penelitian terbagi dua, yakni informan yang terlibat dalam manajemen pemberitaan berita kriminal dalam program Tangkis iNews TV, yakni para kru iNews TV Medan, mulai dari Kepala Biro, Produser Program, Kepala editor, Kordinator Kameramen, dan Presenter. Sedangkan untuk mendapatkan data tentang kepuasan pemirsa dilakukan wawancara dengan pemirsa iNews TV Medan yang berusia antara 30-50 tahun.

\section{HASIL DAN PEMBAHASAN}

Penjelasan tentang manajemen pemberitaan kriminal pada program acara iNews TV dilihat dari prinsip manajemen POAC yakni Planning, Organising, Actuating dan Controling. Sedangkan untuk menjelaskan kepuasan pemirsa terhadap pemberitaan kriminal pada program acara iNews TV dilihat dari: 1) Motif Informasi (Surveillance) adalah berkenaan dengan kebutuhan individu akan informasi dan eksplorasi sosial. Motif ini berkaitan dengan kebutuhan informasi, pengetahuan umum dan ilmu yang dingin di dapat dari menonton sebuah tayangan. 2)
Motif Identitas Pribadi (Personal Identity) adalah referensi diri, penguatan nilai, motif yang ditujukan untuk memperkuat atau menonjolkan sesuatu yang penting dalam kehidupan atau situasi khalayak yang bersangkutan. 3) Motif Integrasi dan Interaksi Sosial (Personal Relationship) adalah motif yang meliputi interaksi dan integrasi sosial, merujuk pada kelangsungan hubungan individu tersebut dengan orang lain, persahabatan, kegunaan sosial. 4) Motif Hiburan (Diversion) adalah motif yang meliputi kebutuhan untuk melepaskan diri dari rutinitas, tekanan dan masalah, sarana pelepasan emosi, kebutuhan akan hiburan.

Untuk memahami berita dalam kegiatan jurnalisme, maka dapat dikemukakan beberapa unsur berita dengan menggunakan rumus $5 \mathrm{~W}$ dan $1 \mathrm{H}$, yang dijabarkan sebagai berikut (Junaedi, 2011: 11): 1) What berarti apa yang terjadi/ akan terjadi. Ini berkaitan dengan apa yang diberitakan. Dalam jurnalisme, what menunjukkan tema apa yang diangkat dalam berita dan harus melihat kelayakannya. 2) Who (Siapa), berarti kepada siapa suatu peristiwa terjadi, atau siapa yang melakukan atau terlihat peristiwa apa. Who harus berkaitan dengan what sehingga mampu memberikan informasi yang cukup kepada khalayak sekaligus dapat mendekatkan berita dengan khalayak. Who bisa mencakup nama, alamat, asal, gelar dan sebagainya yang memperkaya informasi. 3) Where (Dimana), menunjukkan dimana peristiwa yang diberitakan terjadi. Unsur where memberikan informasi tentang lokasi peristiwa yang diberitakan. 4) When (Kapan) memberikan informasi tentang kapan peristiwa tersebut terjadi. Jika tidak ada unsur ini, khalayak akan kebingungan kapan peristiwa yang diberitakan terjadi, apakah sedang terjadi saat diberitakan, kemarin, seminggu yang lalu, sebulan yang lalu, atau bahkan setahun yang lalu. 5) Why (Mengapa), memberikan keterangan tentang mengapa peristiwa tersebut terjadi. Di sini pembuat berita dituntut kemampuannya untuk mampu menggali informasi mengapa 
peristiwa terjadi dan kemudian menjadikannya berita. 6) How (Bagaimana), menjelaskan bagaimana peristiwa yang diberitakan terjadi. Sebagai contoh: "Unjuk rasa mahasiswa ini berakhir ricuh setelah polisi membubarkan paksa aksi unjuk rasa dengan menembakkan gas air mata."

Banyaknya berbagai peristiwa yang terjadi dalam kehidupan manusia menyebabkan perlu kiranya ada kriteria peristiwa atau informasi yang layak disebutberita. Untuk menguji apakah suatu informasi layak menjadi berita, Mencher dalam (Baksin, 2009: 50) membaginya ke dalam tujuh nilai berita: 1) Timeless, artinya kesegaran waktu, peristiwa yang baru-baru terjadi atau aktual. 2) Impact, artinya suatu kejadian yang dapat memberikan dampak terhadap orang banyak. 3) Prominence, artinya suatu kejadian atau yang mengandung nilai keagungan bagi seseorang atau lembaga. 4) Proximity, artinya suatu peristiwa yang ada kedekatannya dengan seseorang, baik secara geografis maupun emosional. 5) Conflic, artinya suatu peristiwa atau kejadian yang mengandung pertentangan antara seseorang, masyarakat atau lembaga, yang berbentuk fisik (perseteruan kelompok) dan non fisik (perbedaan pendapat). 6) The Unusual, artinya sesuatu kejadian atau peristiwa yang tidak biasanya terjadi dan merupakan pengecualian dari pengalaman sehari-hari. 7) The Currency, artinya hal-hal yang sedang menjadi bahan pembicaraan orang banyak.

Sementara itu Charnley lebih menyoroti aspek kualitas berita (the qualities news). Menurutnya ada beberapa standar yang dipakai untuk mengukur kualitas berita: 1) Accurate, artinya sebelum berita itu disebarluaskan harus dicek dulu ketepatannya. 2) Properly attributed, artinya semua saksi atau narasumber harus punya kapabilitas untuk memberikan kesaksian atau informasi tentang yang diberitakan. 3) Balanced and fair, artinya bahwa semua narasumber harus digali informasinya secara seimbang. 4) Objective, artinya penulis berita harus objektif sesuai dengan informasi yang di dapat dari realitas, fakta, dan narasumber. 5) Brief and focused, artinya materi berita disusun secara ringkas, padat dan langsung sehingga mudah dipahami. 6) Well written, artinya kisah beritanya jelas, langsung dan menarik. (Charnley, 1965).

Menurut kamus besar Bahasa Indonesia berita kriminal adalah berita atau laporan mengenai kejahatan yangg diperoleh dari polisi.Berita yang termasuk ke dalam berita kejahatan adalah pembunuhan, penipuan, pemerkosaan, pencopetan, pencurian, perampokan, narkoba, tawuran, penganiayaan dan sebagainya yang melanggar hukum.

Dimana dan kapan saja, berita kriminal mampu menarik perhatian khalayak untuk mencari tahu apa yang terjadi di sekitar mereka.Secara harafiah kriminologi berasal dari kata"crime" yang berarti kejahatan atau penjahat dan "logos" yang berarti ilmu pengetahuan.Apabila dilihat dari kata-kata tersebut kriminologi adalah pengetahuan kejahatan.Pengertian harafiah tersebut memberikan kata pada suatu pengertian yang sempit bahkan dapat juga merumuskan pada pengertian yang salah.

Suther Land dan Chresey mengemukakan bahwa yang dimaksud dalam pengertian kriminologi adalah proses pembentukan hukum, pelanggaran hukum dan relasi terhadap pelanggaran hukum. Dengan demikian, kriminologi tidak hanya mempelajari tentang masalah kejahatan saja tetapi juga meliputi proses pembentukan hukum, pelanggaran hukum, serta reaksi yang diberikan para pelaku kejahatan. (Meda, 1995:83)

Informasi yang menyajikan suatu berita kriminal yang membahas tentang kejahatan dan kekerasan didalam lingkup hukum yang ada di Indonesia, dalam pembuatan atau pencarian data, yaitu data di tempat kejadian perkara dan mempunyai fakta dan aktual yang bersinggungan dengan badan hukum, sepertiberita pencurian sepeda motor, pencurian di rumah kosong, perampasan, pembunuhan, kekerasan dalam rumah tangga, 
pelecehan seksual, itu semua menjadi informasi kriminal yang dikemas dalam suatu berita yang ditayangkan dalam program berita kriminal.

Kata manajemen berasal dari Bahasa Latin, yaitu asal kata manus yang berarti tangan dan agree yang berarti melakukan. Kata-kata itu digabung menjadi kata kerja manager yang artinya menangani. Salah satu aspek kunci dalam manajemen adalah bagaimana manajer dapat mengenali peran dan pentingnya para pihak yang akan menunjang pencapaian tujuan perusahaan. Terry (Suprapto, 2011) mendefinisikan manajemen merupakan sebuah proses yang khas, yang terdiri dari tindakan-tindakan yaitu perencanaan, pengorganisasian, penggiat, dan pengawasan yang dilakukan menentukan serta mencapai sasaran yang telah ditetapkan melalui pemanfaatan sumber daya manusia dan sumber-sumber lainnya. Adapun unsurunsur dalam manajemen menurut Terry (Sondang 2007) yaitu: 1) Perencanaan (Planning), merupakan penyusunan langkahlangkah yang akanditempuh dalam mencapai tujuan. Merencanakan berarti mempersiapkan segala kebutuhan, memperhitungkan matangmatang apa saja yang menjadi kendala, dan merumuskan bentuk pelaksanaan kegiatan yang bermaksud untuk mencapai tujuan. 2) Pengorganisasian (Organizing), dalam hal ini kegiatan yang dilakukan yakni penempatan staf dan pemaduan segala sumberdaya organisasi. Penempatan staff sangat penting dalam organisasi. Dengan menempatkan orang yang tepat pada tempat yang tepat dalam organisasi, maka kelangsungan aktivitas organisasi tersebut akan terjamin. Fungsi pemimpin disini adalah mampu menempatkan the right man in the right place. 3) Pelaksanaan (Actuating), yaitu menggerakkan anggotaanggota kelompok agar mau bekerja dengan sendirinya atau dengan kesadaran secara bersama-sama untuk mencapai tujuan dikehendaki secara efektif. 4) Pengawasan (Controlling), pengendalian atau pengawasan merupakan kegiatanuntuk memantau, membuktikan, dan memastikan seluruh kegiatan yang telah direncanakan agar berjalan sesuai target yang di harapkan.

Teori Uses and Gratification mencoba menjelaskan tentang bagaimana audiens memilih media yang mereka inginkan. Dimana audiens/ khalayak yang secara aktif memilih dan memiliki kebutuhan dan keinginan yang berbeda-beda di dalam mengkonsumsi media.Menurut para pendirinya, Elihu Katz, Jay G. Blumlerm dan Michael Gurevitch, uses and gratifications meneliti asal mula kebutuhan secara psikologis dan sosial, yang menimbulkan harapan tertentu dari media massa atau sumber-sumber lain, yang membawa pada pola terpaan media yang berlainan, dan menimbulkan pemenuhan kebutuhan.

Model Uses and Gratification menunjukkan bahwa yang menjadi permasalahan utama bukanlah bagaimana media mengubah sikap dan perilaku khalayak, tetapi bagaimana media memenuhi kebutuhan pribadi dan sosial khalayak. Jadi, bobotnya ialah pada khalayak yang aktif, yang sengaja menggunakan media untuk mencapai tujuan khusus. Model ini memulai dengan lingkungan sosial yang menentukan kebutuhan kita.Lingkungan sosial tersebut meliputi ciriciri afiliasi kelompok dan ciri-ciri kepribadian.Kebutuhan individual seperti kebutuhan kognitif, kebutuhan afektif, kebutuhan pribadi secara integrative, dan kebutuhan sosial secara integrative. (Effendy, 2007: 294)

Kebutuhan kognitif, adalah kebutuhan yang berkaitan dengan informasi, pengetahuan dan pemahaman mengenai lingkungan. Kebutuhan ini di dasarkan pada hasrat untuk memahami dan menguasai lingkungan, juga memuaskan rasa penasaran kita dan mendorong untuk menyelidiki. Kebutuhan afektif, yaitu kebutuhan yang berkaitan dengan peneguhan pengalaman-pengalaman yang estetis, menyenangkan dan emosional. Kebutuhan pribadi secara integrative, yakni kebutuhan yang berkaitan dengan kredibilitas, 
kepercayaan, stabilitas, dan status individual. Hal-hal tersebut diperoleh dari hasrat dan harga diri. Kebutuhan sosial secara integrative, yaitu kebutuhan yang berkaitan dengan peneguhan kontak dengan keluarga, teman dan dunia. Hal-hal tersebut didasarkan pada hasrat untuk berafiliasi. Kebutuhan pelepasan (Escapist needs), kebutuhan yang berkaitan dengan upaya menghindarkan tekanan, ketegangan, dan hasrat keanekaragaman.

Untuk memperoleh dan mengetahui bagaimana prosedur manajemen dalam program berita kriminal Tangkis iNews TV, peneliti melakukan wawancara dengan timyang terlibat dalam penayangan program berita kriminal Tangkis, yang terdiri dari Kepala Biro (sebagai penanggungjawab tim), produser (sebagai penanggungjawab program), tim editing, kru kameramen studio dan presenter program berita kriminal Tangkis.

Manajemen pemberitaan berita kriminal dalam program Tangkis iNews TV diawali dari sebuah redaksi pemberitaan, yang terdiri dari kordinator liputan atau korda asisten korda, dan produser yang bekerja secara cepat Mereka membaca informasi atau berita yang dikirim oleh kontributor atau wartawan yang berada di lapangan, berbicara di telpon, mengetik naskah berita yang dikirim melalui internet, mengecek gambar, dan beradu argument satu sama lain untuk menentukan berita yang akan ditayangkan.

Pada tahap perencanaan, produser merangkum berita-berita kriminal yang dikirim kontributor atau wartawan ke link berita iNews TV yakni sunbiromedan@gmail.com, mengirim visual ke link sendvideodan menentukan berita-berita apa saja yang akan ditayangkan, menentukan durasi berita, melakukan proses edit naskah, mengecek gambar sesuai dengan naskah yang di edit, menentukan headline dan menyusun berita sesuai segmen dalam sebuah rundown (susunan berita). Dalam penyusunan rundown, berita tangkis dibagi dalam tiga segmen dengan jumlah tujuh atau delapan topik berita, segmen pertama berisi berita-berita yang terhangat, kasus-kasus kriminal dan tindakan kejahatan lainnya serta peristiwa.Segmen kedua memuat berita paparan, sidang pengadilan, dan peristiwa kriminal lainnya, sedangkan segmen ketiga berisi berita-berita ringan, yang sifatnya mengingatkan masyarakat agar tetap waspada, kasus-kasus kriminal di masyarakat, dan lain sebagainya.

Pada tahap pengorganisasian, produser sebagai penanggungjawab program berita, melakukan koordinasi kepada eksekutif produser dan juga kepala divisi pemberitaan terkait berita yang akan ditayangkan. Juga melakukan koordinasi dengan tim editing, dubber (pengisi suara), untuk proses paket berita, sesuai naskah dan gambar yang ditentukan produser. Pada tahap ini, produser berkoordinasi dengan tim editing, terkait kwalitas dan efisiensi waktu, karena proses editing naskah dan gambar, membutuhkan waktu pengerjaan 20-30 menit per berita, dengan jumlah berita dalam satu program ada 7 atau 8 berita yang harus diselesaikan oleh tim editor. Sehingga seorang editor harus bisa memaksimalkan waktu dalam proses pengeditan naskah dan gambar.

Selanjutnya pada tahap pelaksanaan, seluruh paket berita yang sudah disusun produser dalam rundown dan telah selesai proses editing, paket berita yang dikemas untuk program berita kriminal tangkis, siap untuk ditayangkan dan dikirim ke ruang kendali siar. Produser sebagai penanggungjawab program berkoordinasi dengan kepala studio, kepala MCR (Master control Room), untuk memastikan berita sudah tersusun dalam play box studio dan play box MCR, dan siap untuk proses penanyangan berita. Dan pada tahap pengawasan, produser sebagai penanggungjawab program memastikan kembali seluruh paket berita yang akan ditayangkan dan juga seluruh tim yang bertugas, mulai dari tim editing, kameramen, kru MCR, dan make up artis, termasuk juga presenter, untuk proses live sesuai jadwal program berita yang berjalan. Dan selanjutnya 
melakukan evaluasi kepada semua tim setelah siaran selesai tayang.

Tim redaksi setiap hari bekerja mulai dari hari Senin hingga Jumat, dengan dealine seluruh berita yang telah diedit oleh produser, harus masuk ke meja tim editor paling lama pukul 12.00 wib, dengan jam tayang pada pukul 14.30-15.00 wib untuk program berita kriminal Tangkis, dan pukul 15.00-15.30 wib untuk program Sumut Today.

Dari penelitian ini, peneliti juga memperoleh informasi bagaimana proses manajemen pemberitaan secara network, di mana iNews TV biro Medan juga memiliki kewajiban untuk mendistribusikan berita kepada televisi jaringan lainnya untuk ditayangkan secara nasional. Dari wawancara yang dilakukan peneliti dengan Direktur pemberitaan iNews TV Pusat, Arya Sinulingga menyebutkan, ada dua sumber berita untuk daerah yang tayang secara nasional yakni, usulan berita dari kontributor, dan whislist dari tim produksi pemberitaan. Dengan system kerja, sumber berita yang diperoleh diolah oleh tim produksi daerah dan dijadikan usulan rundown ke Manager Produksi dan Pemred Network. Setelah rundown disetujui, maka tim produksi akan memulai memproses pengerjaan produksi dibantu tim grafis dan editor. Selanjutnya, paket berita siap tayang dan masuk ke tim studio dan mulai ditayangkan di program berita.

Kepuasaan Pemirsa

\begin{tabular}{|l|l|l|}
\hline Usia & 000 & $\%$ \\
\hline $5-9$ & 4,028 & $3 \%$ \\
\hline $10-14$ & 4,409 & $4 \%$ \\
\hline $15-19$ & 10,761 & $9 \%$ \\
\hline $20-24$ & 4,323 & $4 \%$ \\
\hline $25-29$ & 12,414 & $10 \%$ \\
\hline $30-39$ & 30,039 & $25 \%$ \\
\hline $40-49$ & 18,578 & $16 \%$ \\
\hline $50+$ & 34,965 & $29 \%$ \\
\hline
\end{tabular}

*Sumber berdasarkan hasil wawancara peneliti dengan Delano Trias Prasetyo, Programming Research \& Development (R\&D) iNews TV.
Kategori pemirsa berdasarkan usia ini menjadi acuan peneliti untuk mengetahui secara lebih mendalam terkait kepuasan pemirsa terhadap tayangan berita kriminal dalam program tangkis di iNewsTV Medan. Adapun informan yang peneliti wawancarai secara mendalam, yaitu informan dengan kategori usia 25-29 tahun, 0-39 tahun, 40-49 dan 50 tahun ketas, yang merupakan kelompok usia yang paling banyak. Selain acuan usia, peneliti juga menentukan kategori lainnya, yaitu informan yang pernah menonton tayangan berita Tangkis di iNews TV.

Motif informasi berkenaan dengan kebutuhan individu akan informasi, pengetahuan umum dan ilmu yang ingin di dapat dari sebuah tayangan. Pada motif informasi, peneliti mengajukan pertanyaan kepada informan seputar intensitas menonton berita tangkis, alasan menonton berita tangkis, jadwal tayang berita tangkis, nilai berita dan informasi apa saja yang diperoleh dari berita tangkis.

Dalam penelitian ini, peneliti menemukan dari delapan informan menyatakan bahwa mereka menonton berita kriminal dalam Program Tangkis karena memang membutuhkan informasi seputar kriminal yang marak terjadi saat ini di Medan dan Sumatera Utara. Sebagai televisi lokal, tayangan berita kriminal Tangkis menambah informasi bagi informan seputar berita kriminal, "bangga dengan sajian berita kriminal local Medan, dengan menonton Tangkis menambah informasi seputar berita kriminal di Sumut" (Fauzi Abdullah, informan 1). Peneliti juga menemukan informan sangat mengenal program tangkis yang menayangkan berita-berita peristiwa kriminal, seperti perampokan, kejahatan jalanan, narkoba dan juga persoalan hukum. Namun beberapa informan ada yang kurang mengetahui jam tayang program Tangkis, dan ada juga yang mengusulkan agar jam tayang program berita kriminal Tangkis di jam jam 16.00 wib atau jam 20.00 wib, karena bagi informan sebuah 
tayangan berita akan leluasa dinikmati saat jam santai.

Motif identitas pribadi ditujukan untuk memperkuat atau menonjolkan sesuatu yang penting dalam kehidupan atau situasi khalayak yang bersangkutan.Pada motif identitas pribadi ini, peneliti mengajukan pertanyaan kepada informan tentang muatan nilai berita kriminal tangkis yaitu unsur kriminalitas dan hukum.Peneliti juga mengajukan pertanyaan kepada informan terkait pengalaman terhadap peristiwa kriminal yang terjadi, dan atau mengetahui lokasi peristiwa kriminal yang ditayangkan di program berita Tangkis.

Dari motif identitas pribadi ini peneliti menemukan bahwa informan sangat membutuhkan berita-berita kriminal, hukum dan peristiwa lainnya, untuk mengetahui sekaligus mengantisipasi serta berhati-hati terhadap tindakan kejatahatan yang terjadi di jalanan.Delapan informan tersebut menyatakan bahwa berita-berita kriminal pada program Tangkis iNews TV, sudah memenuhi unsur kriminalitas dan hukum. Hanya saja perlu dikembangkan lagi untuk kasus-kasus tertentu, contoh kasus kejahatan begal, tidak hanya menyampaikan peristiwa kejahatan tetapi juga ada sanksi atas tindakan kejahatan tersebut, yang disertai solusi dan juga tips bagi pemirsayang menonton tayangan berita Tangkis.

Peneliti juga menemukan, dalam keseharian informan merasa sangat dekat dengan peristiwa-peristiwa kriminal, dengan menonton berita kriminal program Tangkis peneliti menilai ada kepuasan informan terhadap berita yang ditayangkan.

Motif yang meliputi integrasi dan interaksi sosial, merujuk pada kelangsungan hubungan individu tersebut dengan orang lain, persahabatan dan kegunaan sosial.Pada motif ini peneliti mengajukan pertanyaan kepada informan tentang ada tidaknya pengaruh setelah menonton berita kriminal Tangkis dalam kehidupan sehari-hari.

Berdasarkan hasil wawancara dengan delapan informan terkait kepuasan pemirsa terhadap tayangan berita kriminal program Tangkis iNews TV, ada pengaruh yang dirasakan informan atas tayangan berita kriminal Tangkis, dari yang tidak tahu menjadi tahu tentang modusmodus kejahatan, sehingga lebih berhati-hati dan waspada pada saat meninggalkan rumah. Tidak hanya itu, dengan adanya program berita kriminal Tangkis, menambah wawasan dan khasanah informasi seputar kriminal bagi informan.

Motif yang meliputi kebutuhan untuk melepaskan diri dari rutinitas, tekanan dan masalah, sarana pelepasan emosi, dan kebutuhan akan hiburan. Pada motif hiburan atau diversion, sebagian besar informan menyatakan ketidakpuasan terhadap penampilan presenter, artikulasi, intonasi dan ekspresi, kostum dan make up. Dari sisi penampilan, informan mencoba membandingkan, penampilan presenter berita kriminal Tangkis dengan presenter televisi nasional, dimana penampilan presenter program Tangkis terlalu kaku dengan logat yang terlalu kedaerahan.

Dari sisi artikulasi, intonasi, dan ekspresi, informan menilai pada saat membawakan berita, gaya dan ekspresi presenter belum masuk ke program berita, sehingga terkesan kaku dan tidak menjiwai. Begitu juga penggunaan make up, informan menilai make up yang digunakan tidak mencerminkan pribadi presenter, sehingga penampilan presenter terkesan tua dari usianya. Tentang kualitas tayangan, umumnya informan menyatakan ketidakpuasannya karena tampilan gambar yang kabur dan jauh dari kualitas standar broadcasting, namun untuk editing gambar dan sinkronisasi audio dan visual, seluruhnya bagus.

\section{SIMPULAN}

Manajemen pemberitaan program berita kriminal Tangkis iNews TV Medan telah dilaksanakan dengan baik, sesuai dengan standar broadcast. Tim yang terlibat dalam program berita kiriminal Tangkis, yang terdiri dari Kepala Biro, Produser, Editor, Kameramen Studio, dan Presenter, sangat memahami 
fungsi dan tugasnya masing-masing, dan terus melakukan komunikasi dan koordinasi untuk satu tujuan agar program berita dapat memberi kepuasan kepada pemirsa yang memiliki motif yang beragam dalam menonton pemberitaan kriminal Tangkis, namun pada unsur penampilan presenter yang meliputi artikulasi, intonasi, ekspresi,kostum, make up, umumnya pemirsa menyatakan ketidakpuasannya. Beberapa catatanyakni presenter program berita kriminal Tangkis iNews TV masih kurang menjiwai atas berita yang disampaikannya.Begitu juga tentang kualitas gambar pada tayangan berita, pemirsa menilai masih jauh dari mutu yang diharapkan.

\section{DAFTAR PUSTAKA}

Baksin, A., (2009). Jurnalistik Televisi (Teori dan Praktik). Simbiosa Rekatama Media. Bandung.

Effendy, O.U., (2007). Ilmu, Teori dan Filsafat Komunikasi. Penerbit PT Citra Aditya Bakti. . (2009). Ilmu Komunikasi Teori dan Praktek. Penerbit PT Remaja Rosdakarya, Bandung.
http://eprints.umm.ac.id/68o8/1/MANAJEMEN_B ERITA_TELEVISI_PADA_MEDIA_NUSANT ARA_CITRA.di download hari rabu, 21 September 2016

http://www.koran-

sindo.com $/$ news.php? $r=5 \& n=55 \&$ date $=2016-$ 07-12, di download hari kamis, o1 sep 2016, pukul 22.00 wib.

https://id.wikipedia.org/wiki/Teori_penggunaan_ dan_pemenuhan_kepuasan, di download hari Senin, 12 Desember 2016, pukul 21.53 wib

Junaedi, F., (2013). Jurnalisme Penyiaran dan Reportase Televisi. Kencana Prenada Media Group, Jakarta.

Manulang, M., (2014). Manajemen. Penerbit Citapustaka Media Perintis, Bandung.

McQuail, D., (2002). Teori Komunikasi Massa, Penerbit Erlangga Jakarta Solihin, Ismail. 2002. Pengantar Manajemen. Penerbit Erlangga. Jakarta.

Morissan, M.A. (2008). Jurnalistik Televisi Mutakhir. Kencana Prenada Media Group, Jakarta.

Muda, D.I., (2006), Jurnalistik Televisi, Remaja Rosda Karya, Bandung.

Mulyana, D,. (2013). Metodologi Penelitian Kualitatif. Penerbit PT Remaja Rosdakarya, Bandung.

(2012). Ilmu Komunikasi Suatu Pengantar. Penerbit PT Remaja Rosdakarya, Bandung. 